consensus of opinion among medical men that the wetbulb temperature should not exceed $70^{\circ} \mathrm{F}$. to $75^{\circ} \mathrm{F}$, and that operatives should not be called on to work above this limit.

In regard to ventilation, some surprise will be expressed that the report recommends an increase in the permissible amount of carbon dioxide to 12 volumes in 10,000 instead of nine as formerly. Considering the researches of Parkes, Pettenkofer, Angus Smith, Carnelley, and others, all of whom recommend a much lower limit, it is not surprising to find that the committee brings forward a considerable amount of evidence in support of what it evidently considers may be regarded as a reactionary proposal, and it must at once be admitted that there is a good deal to be said in its support. The evidence submitted to it shows that in coal mines the average amount of carbon dioxide is 35 volumes in 10,000 , and such air does not appear to have an injurious effect on the miners. No doubt this is explained by the fact that this carbon dioxide is formed by oxidation of carbon, and is not mainly due to respiration as it is in weaving sheds.

Eminent medical authorities, both in this country, in America, and on the Continent, concur in stating their belief that the ill-effects in crowded rooms are due to excessive heat and humidity rather than to the amount of carbon dioxide. Direct experiments by Haldane and Lorrain-Smith showed that the condensed vapour from respired air, when injected into animals, produced no injurious effects, and their further experiments are " distinctly against the theory that a volatile poison, other than carbonic acid, exists in expired air." Flügge has made an elaborate series of experiments on this subject, and comes to the conclusion that "Temperature, humidity and movement are of enormously greater importance for our comfort and health than the chemical composition of the air." Valuable confirmation of these scientific results comes from the practical experience of the operatives in cotton mills. Thus in one mill, where both dry and wet sheds were under the same roof, the health of the workers was equally good in both, but there was a general desire to transfer to the wet shed, in which the carbon dioxide in the air varied between 34 and $4 \mathrm{I}$ volumes in 10,000 .

Another point to which the attention of the committee was directed was the quality of the water used for the supply of steam. If from an impure source, injurious organic matter may be introduced, and it is suggested that water used for this purpose should be of a certain legal standard of purity. The other recommendations of the committee may be surmised from what has been said already.

\section{RETURN OF THE BRITISH ANTARCTIC EXPEDITION.}

THE British Antarctic Expedition ship Nimrod has returned to New Zealand with Lieut. E. H. Shackleton and the other members of the landing party safe on board. A long despatch received from Lieut. Shackleton by the Daily Mail reports that he himself, with three other members of the expedition, started on an attempt to reach the. South Pole from Ross Island, at the western end of Ross's Great Ice Barrier, on October 29 of last year. Ross Island was reached again at the beginning of this month, the explorers having achieved in the interval-122 daysa journey of 1708 statute miles, in the course of which they reached a point in latitude $88^{\circ} 23^{\prime} \mathrm{S}$. and longitude $162^{\circ} \mathrm{E}$., or only about III miles from the South Pole.

Pushing beyond the most southerly point reached by members of the National Antarctic Expedition on board the Discovery $\left(82^{\circ} 16^{\prime} 33^{\prime \prime}\right.$ S.), Lieut. Shackleton found the high mountains of South Victoria Land trending in a south-easterly direction across his route, and was obliged to ascend a long glacier leading up to a high tableland, on which the explorers eventually reached an altitude of 10,500 feet. Lieut. Shackleton concludes that the South Pole is doubtless situated in this plateau region. The motor-car, though proving useful for transport purposes in the neighbourhood of the winter quarters, was not employed on the southern journey, but the Manchurian ponies were of great assistance.

Another party, under Prof. Edgeworth David, F.R.S., professor of geology in Sydney University, journeyed from the winter quarters northwards along the coast of South Victoria Land to Terra Nova Bay, in about $75^{\circ} \mathrm{S}$., and then ascended to the high plateau-land which stretches inland, and journeyed at an altitude of more than 7000 feet to the south magnetic pole, the position of which was fixed, in the neighbourhood of latitude $72^{\circ} 25^{\prime} \mathrm{S}$., longitude $\mathrm{r}_{5} 4^{\circ} \mathrm{E}$.

On the return voyage, Lieut. Shackleton caught sight of the mountainous northern coast of South Victoria Land, stretching at least forty-five miles south-west and west of Cape North, the previous limit of observation.

Throughout the expedition numerous and varied scientific observations were recorded.

Special interest promises to attach to the geological studies of Prof. David, the biological work of Mr. James Murray, and the meteorological and magnetic observations. We shall hope to return to these when more detailed reports have been received. In some fresh-water lakes near Cape Royd, Mr. Murray found abundant microscopic life. Rotifers were found of remarkable vitality, capable of living for years in the ice of the lakes. Large sheets of a fungus-like plant were found in the lakes, and the vegetation on Ross Island included many lichens and a few mosses. Systematic records were kept of all the appearances of the Aurora australis. An ascent was made of Mount Erebus, 13,120 feet high, by a party under Prof. David; and the old crater of the volcano, which was reached at an altitude of more than II,000 feet, was found to be filled with large felspar crystals, pumice, and sulphur. The south magnetic pole seems to have been located with much exactness.

Judging from the interesting communication to the Daily Mail, a large amount of valuable work has been accomplished. Lieut. Shackleton and the other members of the expedition are to be congratulated upon their remarkable achievements.

\section{UNIFORMITY IN MATHEMATICAL NOTATION} AND PRINTING.

THE subject of establishing a better understanding between mathematical workers and printers has for some time engaged the attention of the council of the Royal Society. It is desirable that the amenities of printing should be considered by authors, so that when there are several ways of writing a formula that one should be employed which is easiest printed and looks best in the published work. It is especially undesirable that different ways should appear at random in the same volume, or even on the same page.

In his anniversary address to the Royal Society on November 30, Lord Rayleigh incorporated a memorandum on this subject, drawn up in the first instance by Prof. Larmor, as an appendix. After recounting earlier efforts in this direction made by a committee of the British Association in 1875 , the paper offers the 
following suggestions, which are here reprinted with a view to their being of use in a wider field :-

Recommendations regarding Mathematical Notation and Printing.

Always,

instead of

$\frac{x}{3} \frac{a+b}{2} \quad \frac{a+\frac{b}{2}}{\frac{c}{3}+\frac{d}{4}} \frac{a}{b+\frac{c}{d}} \quad \sqrt{x} \quad \sqrt{-1} \quad \frac{1}{x} \frac{1}{x^{n}}$

write

$\frac{1}{3} x \frac{1}{2}(a+b) \quad \frac{a+\frac{1}{2} b}{\frac{1}{3} c+\frac{1}{4} d} \quad \begin{gathered}a \\ b+c / d\end{gathered} \quad \sqrt{ } x$ or $x^{\frac{1}{2}} \quad$ เ or $i \quad x^{-1} \quad x^{-n}$

instead of

$$
\text { x. } \overline{x+a}
$$$$
\sqrt{x-y}
$$$$
e^{\frac{n \pi x x}{a}}
$$$$
\int_{0}^{\pi}
$$

write

$$
x(x+a) \quad \sqrt{ }(x-y) \text { or }(x-y)^{\frac{1}{2}}
$$$$
e^{n-\pi x / \alpha}
$$$$
\int^{\frac{3}{2 \pi}}
$$

In current ordinary text, instead of

$$
\begin{array}{cccc}
\frac{x}{a} & \frac{a+b}{c+d} & \frac{x}{v+\frac{t}{2}} & x / y+\frac{a}{b+c} \\
\text { write } & & x /\left(y+\frac{1}{2} t\right) & \frac{x}{y}+\frac{a}{b+c}
\end{array}
$$

Excessive use of the slanting line, or solidus, is, however, undesirable; it may often be avoided by placing several short fractions or formulas, with the intervening words if any, on the same line, instead of setting out each one on a line by itself. The last of the examples given above illustrates an improper use, in which symmetry is spoiled while nothing is gained; either both fractions should be written with the solidus, as $x / y+a /(b+c)$, or else neither as above.

The solidus should be of the same thickness as the horizontal line which it replaces; in some founts of type it is too thick and prominent.

Irregularities in the spacing of letters and symbols in the formulas as printed are often the cause of a general unsatisfactory appearance of the page.

For centimetres, millimetres, kilometres, grams, kilograms, the abbreviations should be $\mathrm{cm}$., mm., km., gm., $\mathrm{kgm}$. (not crms., \&c.), and so in similar cases. Present custom is against the use of the signs $\therefore$ and $\because$

Symbols which are not provided in the usual founts of type are, as a rule, to be avoided. Compounded symbols such as $\dot{a}$ or $\vec{a}$ usually involve justification, and are thus liable to become deranged or broken. The two examples here given have, however, become so essential that separate founts should be provided for them.

The use of a smaller fount for numerical fractions is now customary; thus always $\frac{1}{3} a$ instead of $a / 3$. The use of negative exponents often avoids a complex fractional form; as also the use of the fractional exponents, such as $\frac{1}{2}$ and $\frac{1}{3}$. In the latter case $x^{\frac{1}{2}}$ is usually preferred to $x^{1 / 2}$, notwithstanding that the latter is more legible.

Much is often gained in compactness and clearness by setting out two or more short formulæ on one line, instead of on consecutive lines; in that case they should be separated by spaces, indicated by the sign on the MS. This would apply with even greater force to expressions such as $x=a,=b,=c$.

In the preface to his "Mathematical and Physical Papers," vol. i., 1880, the late Sir George Stokes successfully introduced the limited use of the solidus notation, obtaining the assent and support of Lord Kelvin, Prof. Clerk Maxwell, Lord Rayleigh, the editors of the Annalen der Physik, and many other mathematicians. He defined its use as restricted to the symbols immediately on the two sides of it, unless a brace or stop intervenes; thus $\sin n \pi x / a$ is to mean $\sin (n \pi x / a)$; but $\sin n \theta \cdot / r^{n}$, in case it is used, would mean $(\sin n \theta) / r^{n}$.

No. 2056 , voL. 80$]$

\section{NOTES.}

Prof. Cleveland AbBe, of the U.S. Weather Bureau, Washington, Dr. J. R. Sutton, of Kimberley, South Africa, and M. Léon Teisserenc de Bort, of Paris, have been elected honorary members of the Royal Meteorological Society.

At the meeting of the Royal Geographical Society on April 5, Sir Harry Johnston, who has just returned from his journeys through the southern States and the West Indies, will give a lecture on the scenery of Cuba, Haiti, and Jamaica, with many illustrations from photographs taken by himself.

THE death is announced, at the age of sixty-four years, of Prof. J. W. Moore, professor of physics in Lafayette College at Easton, Pennsylvania, since 1872 .

Sir Rowland Blennerhassett, whose death at sixtynine years of age we announce with great regret, was not only distinguished in his political career and historical studies, but also by his influence upon education in Ireland. For about seven years he was H.M.'s Inspector of Industrial and Reformatory Schools in Ireland. From 1897 to Igo4 he was president of Queen's College, Cork, and in 1905 he was appointed a visitor of the college. He was a senator of the Royal University of Ireland in 1897, and was a member of the standing committee of the Senate. $\mathrm{He}$ was also one of the Commissioners of National Education in Ireland, and took an active part in the administration of that department down to the time of his death.

IT should have been mentioned last week in the article on the Imperial Bureau of Ethnology (p. 73) that the Sirdar, Sir Reginald Wingate, is so impressed with the necessity of a thorough study of native conditions as the basis of good government that he has provided a grant for an investigation of the ethnology of the Sudan, especially from the sociological side. This work, which will extend over at least two winters, has been entrusted to Dr. C. G. and Mrs. Seligmann, who have recently made a joint investigation on the Veddas. Some of our colonial Governments also appreciate the value of such studies. For example, the expedition of the Seligmanns was financed by the Ceylon Government, and Mr. N. W. Thomas has been appointed Government ethnologist to Southern Nigeria, and is at the present time engaged in collecting information concerning the sociology and religion of that district.

THE honorary secretaries of the Zoological Society of Scotland (42 Frederick Street, Edinburgh), which has recently been founded, inform us that the society has been formed for the purpose of establishing a living zoological collection and garden at Edinburgh. The garden will be arranged on the system adopted by Herr Hagenbeck, of Hamburg, and will be conducted on scientific lines. When the society has developed sufficiently, it is within its scope to establish branch gardens in the other large towns in Scotland. In addition to this-its main object-lectures of a popular nature by eminent zoologists will be arranged. The headquarters of the society, and the first and principal garden, will be at Edinburgh. To obtain the necessary capital a garden fund has been opened, to which donations are solicited. The annual subscription is Il. Is., but members who join the society during 1909 pay Ios. only for that year. This will entitle members to all the privileges usual in such a society. The aim of the promoters is to build up a strong society with a large membership, so that a considerable part of the annual sum required for the upkeep of the gardens will be ensured from subscriptions, and less dependence will require to be placed on the receipts from the public for admission. 